\title{
Urban Ecosystem Health Assessment and Its Application in Management: A Multi-Scale Perspective
}

\author{
Meirong Su *, Zhifeng Yang, Bin Chen, Gengyuan Liu, Yan Zhang, Lixiao Zhang, Linyu Xu and \\ Yanwei Zhao
}

State Key Joint Laboratory of Environment Simulation and Pollution Control, School of Environment, Beijing Normal University, Beijing 100875, China; E-Mails: zfyang@bnu.edu.cn (Z.Y.); chenb@bnu.edu.cn (B.C.); liugengyuan@163.com (G.L.); yzhang@bnu.edu.cn (Y.Z.); zhanglixiao@bnu.edu.cn (L.Z.); xly@bnu.edu.cn (L.X.); awei-a@163.com (Y.Z.)

* Author to whom correspondence should be addressed; E-Mail: sumr@bnu.edu.cn; Tel.: +86-10-5880-1763; Fax: +86-10-5880-0397.

Received: 12 November 2012; in revised form: 6 December 2012 / Accepted: 16 December 2012 / Published: 20 December 2012

\begin{abstract}
Urban ecosystem health assessments can be applied extensively in urban management to evaluate the status quo of the urban ecosystem, identify the limiting factors, identify key problems, optimize the scheme and guide ecological regulation. Regarding the multi-layer roles of urban ecosystems, urban ecosystem health should be assessed at different scales with each assessment providing a specific reference to urban management from its own viewpoint. Therefore, a novel framework of multi-scale urban ecosystem health assessment is established on global, national, regional and local scales. A demonstration of the framework is shown by using a case study in Guangzhou City, China, where urban ecosystem health assessment is conducted in the order of global, national, regional, and local scales, from macro to micro, and rough to detailed analysis. The new multi-scale framework can be utilized to generate a more comprehensive understanding of urban ecosystem health, more accurate orientation of urban development, and more feasible regulation and management programs when compared with the traditional urban ecosystem health assessment focusing at the local scale.
\end{abstract}

Keywords: urban ecosystems; health; multi-scale; Guangzhou 


\section{Introduction}

As a center of production and consumption, urban ecosystems have satisfied human demands throughout most of history. Until recently, the stress of resource depletion and emission of pollutants has remained within the ecosystem's regenerative capacity, and the urban ecosystem was able to self-restore. However, with rapid urbanization, more and more intensive human activities have led to adverse environmental changes that impair societal services and jeopardize sustainability [1]. People have begun to worry about whether the urban ecosystem can support dense populations and provide sustainable services. Therefore, urban ecosystem health has become a scientific topic and a goal of urban development, which integrates the means by which human demands are satisfied with the ecosystem's ability for renewal $[2,3]$.

Owing to its acceptability for managers and the general public, the concept of urban ecosystem health has been extensively applied in practical urban planning and management. Particularly, urban ecosystem health assessments have been widely conducted to comprehensively measure the operations of urban ecosystems, identify limiting factors and provide suggestions for urban management. Accelerated by practical demand, the assessment indicators [4-8] and methods [9-13] have developed quickly on a scientific foundation $[14,15]$.

Reviewing this development, urban ecosystem health assessments are usually conducted on the local scale. In fact, the urban ecosystem is a typical complex open system that links closely with its surroundings through various energy and material flows as well as information circulation. Regarding this intrinsic linkage and influence within urban ecosystem itself and its wider surroundings, the urban ecosystem should be conceptualized at multiple layers. Here, the urban ecosystem plays different roles with different functions. Based on this concept, urban ecosystem health assessments at multiple scales are necessary, which will contribute to a multi-faceted understanding of urban ecosystem health status and provide more references for urban management.

In this paper, a novel framework of multi-scale urban ecosystem health assessment and its applications in management are established from the global, national, regional and local scale view points. It is established considering the concerned factors of urban ecosystem health and multi-layer roles of urban ecosystem. Following this, the paper demonstrates an application of the framework using Guangzhou City, China as a case study. The last section offers some discussion and conclusions.

\section{Factors of Concern for Urban Ecosystem Health}

Urban ecosystem health is a holistic conception that integrates various factors, such as economic development, social progress, environmental quality, and population health. Meanwhile, it not only emphasizes the current situation but also has a dynamic objective. To understand urban ecosystem health as comprehensively and concisely as possible, we explain it from three dimensions, as shown in Figure 1.

(1) The traditional dimension lies on the horizontal axis. The concept of ecosystem health (for natural ecosystems) has developed by only focusing on the characteristics of the ecosystem itself [16] or only on services for humans $[17,18]$. This has resulted in a combination of characteristics of ecosystems and services for humans $[2,3]$. Therefore, the concept of urban ecosystem health naturally 
combines the ability to satisfy reasonable human demands and maintain its own renewal and self-generative capacity since its inception.

(2) The stress dimension lies on the eleven-five o'clock axis. A healthy urban ecosystem not only performs well in terms of structural stability and functional completeness under normal conditions, but it also has a strong ability to adapt and recover under serious threat.

(3) The temporal dimension lies on the one-seven o'clock axis. Urban ecosystem health regards the growth and development potential for the future as equally important as the current and previous health status, guided by ideas of sustainable development. Attributed to its value-driven characteristics that are strongly influenced by human perceptions [19], urban ecosystem health should be conceptualized as a process [20,21], which can give us much more hope and impel us to focus more studies on the dynamic trends of health status.

Figure 1. Factors of concern for urban ecosystem health. (UEH is used in this figure to represent urban ecosystem health).

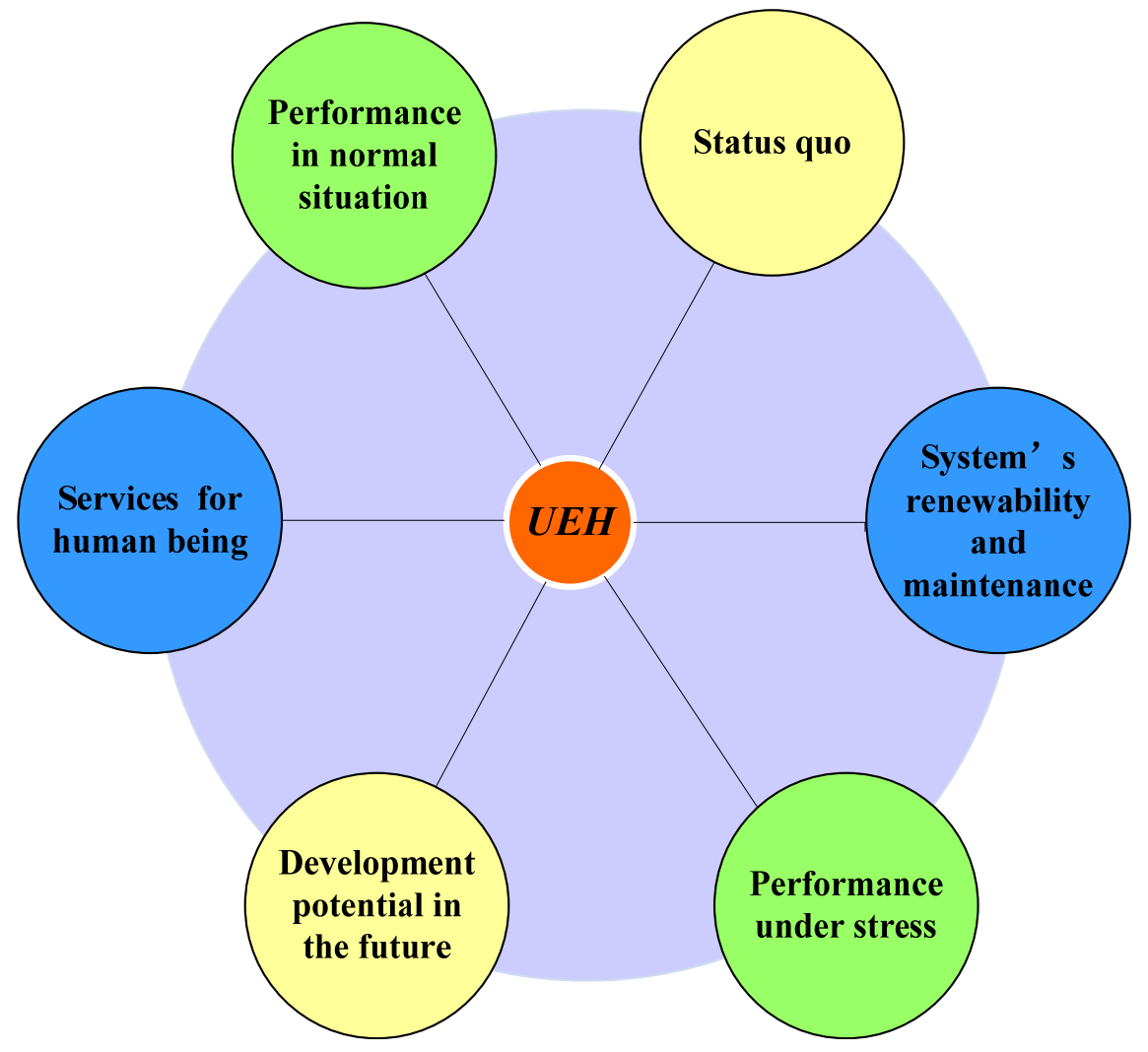

\section{Multi-Layer Roles of Urban Ecosystems}

Although urban ecosystem health is described in terms of the three dimensions in Section 2, the focus restricts only on the layer of the urban ecosystem itself. Each system has multiple roles at different layers with different functions [22-24]. Similarly, urban ecosystems can be analyzed from different layers with each analysis helping to understand and provide a special reference to urban ecosystem health from its own viewpoint (see Figure 2).

(1) At the local layer, the urban ecosystem itself is a whole system composed of multiple subsystems and various elements. It has its own holistic structure and diverse functions with special 
characteristics of temporal and spatial change. Urban ecosystem health assessments can verify whether the structure is reasonable, whether different subsystems are harmonious with each other, whether its function is complete, and whether the change in trends is acceptable and sustainable.

(2) At the regional layer, different adjacent urban ecosystems interact with each other. Because of the spatial adjacency, they share similar natural conditions and culture, thus there exists an opportunity for both cooperation and completion. Good relationships among different urban ecosystems will bring environmental benefits (e.g., improving resources usage efficiency), which may further lead to improvement of its urban ecosystem health status.

Figure 2. Multi-layer roles of urban ecosystems and respective concerns.

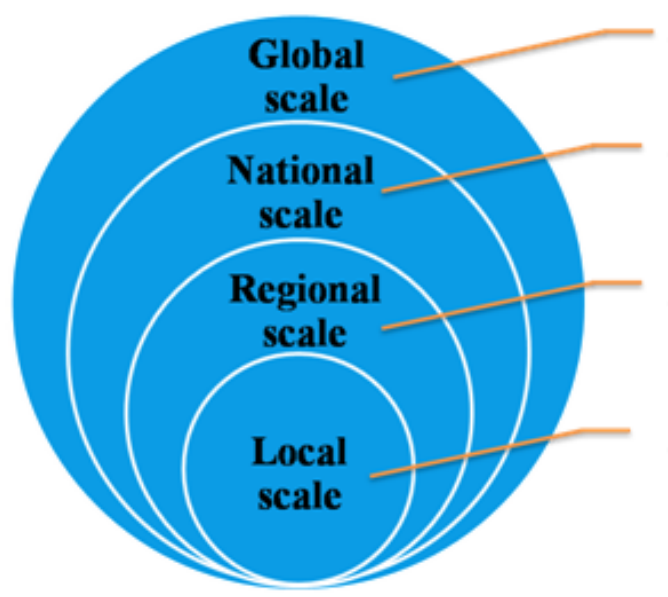
A point in the world: Lessons from global development trend A part in the state: Classification and orientation in the national development

A section in the region: Relationship among adjacent urban ecosystems

A whole urban system: Structure and function

(3) At the national layer, different regions or urban ecosystems play different roles according to the national development strategy. The macro-orientation of a concerned urban ecosystem needs to be considered to objectively understand different classifications of urban ecosystem health modes.

(4) At the global layer, international development trends and long-term systemic characteristics of human-environment relations influence every urban ecosystem [25]. Valuable experience from urban environmental management and ecological construction can contribute to improvement of the health of concerned urban ecosystems.

\section{Multi-Scale Urban Ecosystem Health Assessment and Its Applications in Management}

Combining the above-mentioned factors of urban ecosystem health and multi-layer roles of urban ecosystems, a novel framework of multi-scale urban ecosystem health assessment applications in management is established, as indicated in Figure 3, which summarizes urban ecosystem health assessment, potential findings of urban ecosystem health assessment, and corresponding contribution for urban management on the global, national, regional and local scales.

Traditionally, the urban ecosystem health assessment is restricted to a local scale, ignoring the multi-layer roles of the urban ecosystem. Here, by analyzing urban ecosystems from multiple scales and applying the multi-scale urban ecosystem health assessment, a more comprehensive viewpoint, more accurate orientation, and more feasible program can guide urban regulation and management. The urban ecosystem health assessment can be conducted in the order of global, national, regional, and 
local scales, from macro to micro, and rough to detailed analysis. The analysis at larger scales can continuously guide urban management in this way.

Figure 3. Framework of multi-scale urban ecosystem health assessment and its implications in management.

\begin{tabular}{|c|c|c|c|c|}
\hline & Global scale & National scale & Regional scale & Local scale \\
\hline $\begin{array}{l}\text { Focus of urban } \\
\text { ecosystem } \\
\text { health (UEH) } \\
\text { assessment }\end{array}$ & $\begin{array}{l}\text {-Long-term } \\
\text { development trends } \\
\text {-Restorative measures } \\
\text { after certain disasters } \\
\text {-Comparison among } \\
\text { international cities }\end{array}$ & $\begin{array}{l}\text {-Comparison among } \\
\text { different cities } \\
\text {-Clustering analysis of } \\
\text { UEH }\end{array}$ & $\begin{array}{l}\text {-Comparison and } \\
\text { further analysis among } \\
\text { adjacent cities } \\
\text {-Interaction among } \\
\text { adjacent cities }\end{array}$ & $\begin{array}{l}\text {-Characteristics of UEH } \\
\text {-Detailed comparison and } \\
\text { analysis among different } \\
\text { subsystems and spatial units }\end{array}$ \\
\hline $\begin{array}{l}\text { Potential } \\
\text { findings }\end{array}$ & $\begin{array}{l}\text {-Evolution rule of UEH } \\
\text { patterns } \\
\text {-Measures of coping } \\
\text { with serious threat }\end{array}$ & $\begin{array}{l}\text {-Spatial distribution of } \\
\text { ecosystem health for } \\
\text { different cities } \\
\text {-Classification of UEH } \\
\text { patterns }\end{array}$ & $\begin{array}{l}\text {-Identification of } \\
\text { concrete limiting indexes } \\
\text {-Restriction and support } \\
\text { by adjacent cities }\end{array}$ & $\begin{array}{l}\text {-Change of UEH states } \\
\text { during study period } \\
\text {-Difference among different } \\
\text { subsystems and spatial units }\end{array}$ \\
\hline $\begin{array}{l}\text { Implications for } \\
\text { urban } \\
\text { management }\end{array}$ & $\begin{array}{l}\text {-International trends in } \\
\text { urban development (e.g., } \\
\text { low-carbon cities and } \\
\text { compact cities) } \\
\text {-International } \\
\text { experience (e.g., } \\
\text { transportation, greening, } \\
\text { and environmental } \\
\text { protection) } \\
\text {-Unique features }\end{array}$ & $\begin{array}{l}\text {-Macro-orientation } \\
\text { (e.g., economic center } \\
\text { and cultural center) } \\
\text {-Experience of other } \\
\text { cities } \\
\text {-Limiting factors (e.g., } \\
\text { economic development } \\
\text { and natural condition) }\end{array}$ & $\begin{array}{l}\text {-Definition of key fields } \\
\text { based on limiting } \\
\text { indexes (e.g., pollution } \\
\text { control and resource } \\
\text { saving) } \\
\text {-Cooperation with } \\
\text { adjacent cities (e.g., } \\
\text { resources sharing and } \\
\text { industrial symbiosis) }\end{array}$ & $\begin{array}{l}\text {-Optimization based on } \\
\text { spatial differences (e.g-, } \\
\text { industrial distribution and } \\
\text { selection of pollution } \\
\text { discharge position) } \\
\text {-Ecological regulation for } \\
\text { spatial units (e.g., } \\
\text { environmental standards and } \\
\text { ecological restoration) }\end{array}$ \\
\hline
\end{tabular}

\section{Case Study}

Guangzhou, a city located in Guangdong Province, China, helps to illustrate the above framework in more detail. With an area of $7,434.4 \mathrm{~km}^{2}$, Guangzhou is a modern metropolitan region that supports a population of over 8.0 million (2010 data from [26]). It is the political, economic, and cultural center of Guangdong Province and serves as a commercial, financial, and information center in South China.

Table 1. Multi-scale urban ecosystem health assessment for Guangzhou and its implications for management.

\begin{tabular}{|c|c|c|}
\hline Scale & Global scale & National scale \\
\hline & & Guangzhou and other Chinese cities like \\
\hline $\begin{array}{l}\text { Results of } \\
\text { urban } \\
\text { ecosystem } \\
\text { health } \\
\text { assessment }\end{array}$ & $\begin{array}{l}\text { Environmental quality is the main } \\
\text { constraint of urban performance, } \\
\text { especially as the air quality is } \\
\text { low [27]. }\end{array}$ & $\begin{array}{l}\text { Beijing, Tianjin, and Shanghai, with relative } \\
\text { weak health levels, are classified in the same } \\
\text { group. Their common characteristics include } \\
\text { high urbanization, high industrialization, and } \\
\text { high environmental impacts. The latter is the } \\
\text { main restriction of health levels [12]. }\end{array}$ \\
\hline
\end{tabular}

Table 1. Cont.

\begin{tabular}{ccc}
\hline Scale & Global scale & National scale \\
\hline Implications for & Measures aiming at creatinga green city, & As a regional economic center, various \\
\hline
\end{tabular}




\begin{tabular}{|c|c|c|}
\hline management & $\begin{array}{l}\text { eco-city, compact city, and low-carbon } \\
\text { city in international cities are useful } \\
\text { reference points. Holistic regulation of } \\
\text { land use, public transportation, energy } \\
\text { and resource efficiency, and waste } \\
\text { treatment need be implemented. }\end{array}$ & $\begin{array}{l}\text { activities arelikely to be intensified, supported } \\
\text { by dense energy and flow of resources. Means } \\
\text { of using energy and resourcesefficiently } \\
\text { should be established to pursue harmony } \\
\text { between economic development and } \\
\text { environmental protection. }\end{array}$ \\
\hline Scale & Regional scale & Local scale \\
\hline $\begin{array}{l}\text { Results of } \\
\text { urban } \\
\text { ecosystem } \\
\text { health } \\
\text { assessment }\end{array}$ & $\begin{array}{l}\text { Concrete indicators related to } \\
\text { environmental impact are compared for } \\
\text { Guangzhou and other cities in the Pearl } \\
\text { River Delta. The limiting factors of } \\
\text { Guangzhou are identified aslimited local } \\
\text { renewable energy sources, small carrying } \\
\text { capacity, high dependence on imported } \\
\text { energy and resources, and large amounts } \\
\text { of waste [28]. }\end{array}$ & $\begin{array}{l}\text { The spatial distribution of health levelsin } \\
\text { Guangzhou is revealed.The north of } \\
\text { Guangzhou is defined as a conservation area, } \\
\text { the middle and southern parts are defined as } \\
\text { maintenance areas, while the south central and } \\
\text { southwestern parts are defined as key } \\
\text { regulation areas [29]. }\end{array}$ \\
\hline $\begin{array}{l}\text { Implications for } \\
\text { management }\end{array}$ & $\begin{array}{l}\text { In order to slow down the rate of energy } \\
\text { depletion and reduce dependence on } \\
\text { imports, relevant energy policy and } \\
\text { efficient energy usage needs to be } \\
\text { proposed [30]. Measures on population } \\
\text { control and waste treatment should be } \\
\text { strengthened to enlarge the carrying } \\
\text { capacity. Cooperation among adjacent } \\
\text { cities should be conducted to construct a } \\
\text { circular economic chain and realize the } \\
\text { optimized cost-benefit budget. }\end{array}$ & $\begin{array}{l}\text { Zoning management should be implemented. } \\
\text { Natural resources should be protected and } \\
\text { human activities limited in northern parts of } \\
\text { the region. Measures to improve economic } \\
\text { productivity and energy efficiency, and } \\
\text { maintain indigenous renewable resources } \\
\text { should be implemented in middle and } \\
\text { southern parts of the region. For south central } \\
\text { and southwestern parts, more space should be } \\
\text { allocated for environmental-friendly } \\
\text { production, green consumption patterns } \\
\text { should be promoted, energy demands should } \\
\text { be reduced, and waste discharge should be } \\
\text { reduced. }\end{array}$ \\
\hline
\end{tabular}

${ }^{a}$ Non-specific comparison of urban ecosystem health states among Guangzhou and international cities has been done. The results are obtained from comparison among Beijing and international cities.

As demonstrated above, the urban ecosystem health assessment gradually becomes more detailed and focused at smaller scales. The results of the assessment at the macro-scale shape the rough focus at the micro-scale. At the same time, the results at the micro-scale show concrete decomposed situations and provide more applicable and acceptable suggestions for urban regulation and management.

\section{Discussion and Conclusions}

Urban ecosystem is a typical complex open system. It links closely with its surroundings through energy and material flows, information circulation, and cultural communication. The environment undoubtedly has a great impact on urban development. For a given urban ecosystem, the relationship with adjacent cities and the position in the national development scenario will contribute to an objective understanding of its urban ecosystem health status. However, it does not provide insight into the internal situation of the urban ecosystem itself. Therefore, urban ecosystem health assessment at 
multiple scales is necessary, through which comprehensive suggestions can be given for urban regulation and management.

Considering these demands, a novel framework of multi-scale urban ecosystem health assessment and its applications in management is established. Compared with the traditional urban ecosystem health assessment focusing on the urban ecosystem itself, by integrating situations at global, national, regional, and local scales, the new framework can provide a more comprehensive understanding of urban ecosystem health, more accurate orientation for urban development, and more feasible programs of urban regulation and management. From the macro- to micro-scales, the urban ecosystem health assessment becomes more detailed and focused, and then more applicable and acceptable suggestions can be proposed for urban management.

Only a framework of multi-scale urban ecosystem health assessment and its applications in management are established in this paper, and only the Guangzhou case study is given as a rough demonstration. Further work is required on both the theoretical and practice dimensions to amend the framework. With more applications and sufficient data, the quantitative results of urban ecosystem health assessment at different scales can be further compared, based on which more visible results and valuable references can be obtained for actual management. Because the focus and some indicators of urban ecosystem health assessment may differ with the scale of study, the information integrated needs to be analyzed carefully [31], which can be gradually perfected with more studies.

Urban ecosystem health assessments can provide many valuable references for urban management, including status quo assessment and problem identification, optimization of urban planning and management schemes, and effect evaluation of schemes. However, it should be pointed out that many other disciplines and methods are vital for actual urban management, like system science, landscape ecology, network analysis methods, multi-objective programming methods [32-34], ecological suitability analysis methods, sensitivity analysis methods, and cost-benefit analysis methods.

\section{Acknowledgments}

Financial support is provided by the National Natural Science Foundation of China (No. 40901269), the National Science Foundation for Innovative Research Group (No. 51121003), and the Fundamental Research Funds for the Central Universities. The authors would also thank the help of the editor and the comments of the reviewers, which significantly improved the quality of this paper.

\section{References}

1. Vitousek, P.M.; Mooney, H.A.; Lubchenco, J.; Melillo, J.M. Human dominance of Earth's ecosystems. Science 1997, 277, 494-499.

2. O'Laughlin, J. Forest ecosystem health assessment issues: Definition, measurement, and management implications. Ecosyst. Health 1996, 2, 19-39.

3. Rapport, D.J.; Böhm, G.; Buckingham, D.; Cairns, J., Jr.; Costanza, R.; Karr, J.R.; de Kruijf, H.A.M.; Levins, R.; McMichael, A.J.; Nielsen, N.O.; et al. Ecosystem health: The concept, the ISEH, and the important tasks ahead. Ecosyst. Health 1999, 5, 82-90.

4. Harpham, T. Urban health in the Gambia: A review. HealthPlace1996, 2, 45-49. 
5. Takano, T.; Nakamura, K. An analysis of health levels and various indicators of urban environments for Healthy Cities projects. J. Epidemiol. Commun. Health 2001, 55, 263-270.

6. Guo, X.R.; Yang, J.R.; Mao, X.Q. Primary studies on urban ecosystem health assessment (in Chinese). China Environ. Sci. 2002, 22, 525-529.

7. Su, M.R.; Yang, Z.F.; Chen, B.;Ulgiati, S. Urban ecosystem health assessment based on emergy and set pair analysis-A comparative study of typical Chinese cities. Ecol. Model 2009, 220, 2341-2348.

8. Spiegel, J.M.; Bonet. M.; Yassi, A.; Molina, E.; Concepcion, M.; Mast, P. Developing ecosystem health indicators in centro Habana: A community-based approach. Ecosyst. Health 2001, 7, 15-26.

9. Zhou, W.H.; Wang, R.S. An entropy weight approach on the fuzzy synthetic assessment of Beijing urban ecosystem health, China (in Chinese). Acta Ecologica. Sinica. 2005, 25, 1344-1351.

10. Yan, W.T. Research on urban ecosystem health attribute synthetic assessment model and application (in Chinese). Syst. Eng. Theor. Practice 2007, 8,137-145.

11. Su, M.R.; Yang, Z.F.; Chen, B. Relative urban ecosystem health assessment: A method integrating comprehensive evaluation and detailed analysis. Ecohealth 2010, 7, 459-472.

12. Liu, G.Y.; Yang, Z.F.; Chen, B.; Ulgiati, S. Emergy-based urban health evaluation and development pattern analysis. Ecol. Model 2009, 220, 2291-2301.

13. Müller, F.; Lenz, R. Ecological indicator: Theoretical fundamentals of consistent applications in environmental management. Ecol. Indic. 2006, 6, 1-5.

14. Costanza, R.; Norton, B.G.; Haskell, B.D. Ecosystem Health: New Goals for Environmental Management, 1st ed.; Island Press: Washington, DC, USA, 1992.

15. Odum, E.P. Perturbation theory and the subsidy-stress gradient. Bioscience 1979, 29, 349-352.

16. Karr, J.R.;Fausch, K.D.; Angermeier, P.L.; Yant, P.R.; Schlosser, I.J. Assessing Biological Integrity in Running Waters: A Method and Its Rationale, 1st ed.; Illinois Natural History Survey: Champaign, State, USA, 1986.

17. Rapport, D.J. What constitute ecosystem health? Perspect. Biol. Med. 1989, 33, 120-132.

18. Mageau, M.T.; Costanza, R.; Ulanowicz, R.E. The development and initial testing of a quantitative assessment of ecosystem health. Ecosyst. Health 1995, 1, 201-213.

19. Odum, E.P. Ecology and Our Endangered Life-support Systems, 1st ed.; Sinauer Associates: Sunderland, State, USA, 1989.

20. Su, M.R.; Fath, B.D.; Yang, Z.F. Urban ecosystem health assessment: A review. Sci. Total Environ. 2010, 408, 2425-2434.

21. Ramalho, C.E.; Hobbs, R.J. Time for a change: Dynamic urban ecology. Trends Ecol. Evol. 2012, 27, 179-188.

22. Brenner, N. Beyond state-centrism? Space, territoriality, and geographical scale in globalization studies. Theor. Soc. 1999, 28, 39-71.

23. Sassen, S.; Dotan, N. Delegating, not returning, to the biosphere: How to use the multi-scalar and ecological properties of cities. Global Environ. Chang. 2011, 21, 823-834.

24. Cai, Y.P.; Huang, G.H.; Tan, Q.; Liu, L. An integrated approach for climate-change impact analysis and adaptation planning under multi-level uncertainties. Part II: Case study. Renew. Sust. Energ. Rev.2011, 15, 3051-3073. 
25. Mauro, S.E.D. Seeing the local in the global: Political ecologies, world-systems, and the question of scale. Geoforum 2009, 40, 116-125.

26. Guangzhou Municipal Statistics Bureau. Guangzhou Statistical Yearbook 2011 (in Chinese). Available online: http://data.gzstats.gov.cn/gzStat1/chaxun/njsj.jsp (accessed on 6 November 2012).

27. Wang, J.; Su, M.R.; Chen, B.; Chen, S.Q.; Liang, C. A comparative study of Beijing and three global cities: A perspective on urban livability. Front. Earth Sci. 2011, 5, 323-329.

28. Su, M.R.; Yang, Z.F.; Chen, B. Limiting factor analysis of urban ecosystems based on emergy-A case study of three cities in the Pearl River Delta in China. Procedia. Environ. Sci. 2011, 5, 131-138.

29. Su, M.R.; Fath, B.D. Spatial distribution of urban ecosystem health in Guangzhou, China. Ecol. Indic. 2012, 15, 122-130.

30. Donoso, P.; de Grange, L. A microeconomic interpretation of the maximum entropy estimator of multinomial logit models and its equivalence to the maximum likelihood estimator. Entropy 2010, 12, 2077-2084.

31. Smajgl, A.; House, A.P.N.; Butler, J.R.A. Implications of ecological data constraints for integrated policy and livelihoods modelling: An example from East Kalimantan, Indonesia. Ecol. Model. 2011, 222, 888-896.

32. Cai, Y.P.; Huang, G.H.; Tan, Q. An inexact optimization model for regional energy systems planning in the mixed stochastic and fuzzy environment. Int. J. Energ. Res. 2009, 33, 443-468.

33. Tan, Q.; Huang, G.H.; Cai, Y.P. Waste management with recourse: An inexact dynamic programming model containing fuzzy boundary intervals in objectives and constraints. J. Environ. Manage. 2010, 91, 1898-1913.

34. Tan, Q.; Huang, G.H.; Wu, C.Z.; Cai, Y.P.; Yan, X.P. Development of an inexact fuzzy robust programming model for integrated evacuation management under uncertainty. J. Urban. Plan D ASCE 2009, 135, 39-49.

(C) 2013 by the authors; licensee MDPI, Basel, Switzerland. This article is an open access article distributed under the terms and conditions of the Creative Commons Attribution license (http://creativecommons.org/licenses/by/3.0/). 